\title{
Effect of habitual calcium intake on dietary vitamin D requirements in adults
}

\author{
A. Hayes ${ }^{1}$, K. M. Seamans ${ }^{1}$, M. Kiely ${ }^{1}$ and K. D. Cashman ${ }^{1}$ \\ ${ }^{1}$ Vitamin D Research Group, School of Food and Nutritional Sciences, University College Cork, Cork, Ireland
}

If dietary calcium intake is low and serum calcium concentrations decrease, the compensatory metabolic response is the accelerated conversion of 25-hydroxyvitamin D [25(OH)D] to 1,25-dihydroxyvitamin D (via parathyroid hormone), so as to normalize serum calcium levels ${ }^{(1)}$. These interactions between vitamin $\mathrm{D}$ and calcium may have implications for the regulation of $25(\mathrm{OH}) \mathrm{D}$ production and its catabolism, and consequently for the dietary vitamin D requirement ${ }^{(2)}$. While highlighted as a significant knowledge gap by the North American Institute of Medicine in their recent DRI report for vitamin D and calcium ${ }^{(1)}$, to date this hypothesis has only received limited attention in human studies. The aim of this study was to test this hypothesis using relevant data from our previously published vitamin $\mathrm{D}$ intervention studies in $20-40$ y olds ${ }^{(3)}$ and $64+\mathrm{y}$ olds ${ }^{(4)}$ as well as an updated version of our recent meta-regression analysis ${ }^{(5)}$, all of which up to now have not included dietary calcium intake as a possible additional determinant of vitamin $\mathrm{D}$ requirements.

Within the datasets from our two vitamin D intervention studies, baseline serum $25(\mathrm{OH}) \mathrm{D}$ and response of serum $25(\mathrm{OH}) \mathrm{D}$ to vitamin $\mathrm{D}_{3}$ intervention $(0,5,10$ or $15 \mu / \mathrm{d})$ over winter months were stratified by<or $\geqslant$ three different cut-offs for dietary calcium intake $(550,700$ and $800 \mathrm{mg} / \mathrm{d})$, representing EU estimated average requirement (EAR), UK reference nutrient intake and US EAR for calcium, respectively). Students' paired and unpaired $t$-tests were used to test differences at baseline and response of serum $25(\mathrm{OH}) \mathrm{D}$ to intervention in groups stratified according to each cut-off for calcium intake, respectively. Regression models were also run to account for possible confounding effects of sex, age, BMI, habitual vitamin D intake and study centre. In the meta-regression analysis, two new studies published since our original meta-regression in $2011^{(5)}$ were included and habitual calcium intake was reported in each of the 13 studies.

In the meta-regression approach, the relationship between serum $25(\mathrm{OH}) \mathrm{D}$ and total vitamin $\mathrm{D}$ intake were not significantly different $(P>0.05)$ when studies were stratified on the basis of habitual group mean calcium intakes $<$ or $\geqslant \sim 1000 \mathrm{mg} / \mathrm{d}$. Data from our own two intervention studies suggest that while baseline serum $25(\mathrm{OH}) \mathrm{D}$ concentrations were significantly lower $(P<0.05)$ in the $<700 \mathrm{mg} / \mathrm{d}$ calcium intakes groups compared to the $>700 \mathrm{mg} / \mathrm{d}$ in the $64+\mathrm{y}$ olds, these differences disappeared when data was adjusted for the aforementioned confounding factors. There were no other significant differences $(P>0.05)$ in baseline serum $25(\mathrm{OH}) \mathrm{D}$ in $20-40$ y olds or $64+\mathrm{y}$ olds when stratified by habitual calcium intake. Upon stratification on the basis of $<$ or $\geqslant$ three selected dietary calcium intake cutoffs, there was no significant difference in the response of serum $25(\mathrm{OH}) \mathrm{D}$ to vitamin $\mathrm{D}$ intervention over winter in the $20-40 \mathrm{y}$ olds. Likewise, there was no significant difference in response of serum $25(\mathrm{OH}) \mathrm{D}$ to vitamin $\mathrm{D}$ intervention in $64 \mathrm{y}$ olds stratified by $</>550 \mathrm{mg} / \mathrm{d}$ or $</>800 \mathrm{mg} / \mathrm{d}$ but there were lower responses to $5 \mu / \mathrm{d}(12.2 \mathrm{nmol} / \mathrm{L} ; P=0.007), 10 \mu / \mathrm{d}(14.6 \mathrm{nmol} / \mathrm{L} ; P=0.008)$, and $15 \mu / \mathrm{d}(9.4 \mathrm{nmol} / \mathrm{L} ; P=0.097)$ in those $64+\mathrm{y}$ olds with calcium intakes $<$ compared to $\geqslant 700 \mathrm{mg} / \mathrm{d}$. Calcium intake $</>700 \mathrm{mg} / \mathrm{d}$ remained a significant predictor $(P=0.041)$ of the change in serum $25(\mathrm{OH}) \mathrm{D}$ over winter in the regression models that accounted for treatment but also the aforementioned confounding factors.

In conclusion, post-hoc analysis seems to suggest that a habitual calcium intake less than $700 \mathrm{mg} / \mathrm{d}$ may lead to a more blunted response of winter serum $25(\mathrm{OH}) \mathrm{D}$ to increased vitamin D intake in older adults. This may have implications for the dietary vitamin D requirement. *The two vitamin D intervention studies were collaborative studies with the University of Ulster, Coleraine. **Current analysis supported by the Department of Health, England.

1. Institute of Medicine (2011) Washington, DC: The National Academies Press.

2. Clements MR, Johnson L, Fraser DR et al. (1987) A new mechanism for induced vitamin D deficiency in calcium deprivation. Nature 325, 62-65.

3. Cashman KD, Hill TR, Lucey AJ et al. (2008) Estimation of the dietary requirement for vitamin D in healthy adults. Am J Clin Nutr 88, $1535-42$.

4. Cashman KD, Wallace JMW, Horigan G, et al. (2009) Estimation of the dietary requirement for vitamin D in free-living adults $\geqslant 64$ y of age. Am J Clin Nutr 89, 1366-1374.

5. Cashman KD, Fitzgerald AP, Kiely M, et al. (2011) A systematic review and meta-regression analysis of the vitamin D intake-serum 25-hydroxyvitamin D relationship to inform European recommendations. Br J Nutr 106, 1638-48. 